\title{
The importance of predators on a sandflat: interplay between seasonal changes in prey densities and predator effects
}

\author{
Simon F. Thrush, Rick D. Pridmore, Judi E. Hewitt, Vonda J. Cummings \\ Ecosystems Division, National Institute of Water and Atmospheric Research, PO Box 11-115, Hamilton, New Zealand
}

\begin{abstract}
An experiment was designed to assess the role of 2 different predators in determining the macrobenthic community structure of an intertidal sandflat. The 2 predators were: shorebirds which feed throughout the year by removing individual prey items, and eagle rays Myliobatis tenuicaudatus which are only present during the summer and disturb large volumes of sediment when extracting prey. The experiment consisted of bird exclusion, ray + bird exclusion and reference plots. Samples were collected from each plot on 2 occasions: 6 mo after the initiation of the experiment, when rays were absent and common bivalve densities were high following recruitment, and 8 mo later when rays were present and bivalve population structure was not dominated by new recruits. At the end of the experiment analysis of surficial sediment features did not indicate the experiment was confounded by localised modifications of sediment or hydrodynamic conditions. Community level differences on both occasions were driven by effects on common taxa. The seasonality of effects in our experiment precluded direct comparison of the 2 predators. However, the 6 mo results indicated that bird predation resulted in indirect effects due to adult/juvenile interactions amongst the domunant bivalve Macomona liliana. At the end of the experiment, 14 mo after its initiation, analysis of common taxa generally revealed direct negative effects of predation, with significantly high densities in the ray + bird exclusion treatment. Infaunal density changes in response to the exclusion of shorebirds and rays did not indicate the presence of multiple trophic levels in this infaunal assemblage. Differences between the results obtained from the bird exclusion and the ray + bird exclusion treatments on the first sampling occasion were attributed to an edge effect around the bird exclusion plots which effectively increased their area. This edge effect emphasises the importance of infaunal mobility and its potential to swamp predator effects. The results of this experiment highlight the importance of considering the role of predators within an appropriate spatial and temporal context.
\end{abstract}

KEY WORDS: New Zealand · Soft-bottom - Predation · Disturbance - Shorebirds - Eagle rays · Recruitment

\section{INTRODUCTION}

What happens to prey populations and communities when predation intensity changes is difficult to predict (Belsky 1987, Pimm 1991, Wilson 1991). While the number of prey consumed by predators can be calculated from energetic equations, this provides little insight into the influence of predators on the structure of prey populations and communities. Such information can only be obtained from field studies where predator densities are changed. In marine soft-bottom habitats predator densities are frequently manipulated by exclusion experiments which often do not demonstrate negative effects of predators on infaunal densi- ties (e.g. Reise 1977, Virnstein 1977, 1979, Bell \& Coull 1978, Hall et al. 1990). Features of soft-bottom communities used to explain the lack of direct negative effects by predators include: the absence of dramatic resource monopolization and the generalist nature of many predators and prey (e.g. Peterson 1979, Whitlatch 1980), the presence of multiple trophic levels (Commito \& Ambrose 1985), and the mobility of both predators and prey (Thrush 1986, Frid 1989, Hall et al. 1990). Ecological explanations like these presuppose that the original experimental designs were sufficiently powerful to detect predator effects. Sadly, many exclusion experiments (e.g. Reise 1977, Quammen 1984, Raffaelli \& Milne 1987, Hall et al. 1990) have employed low lev- 
els of replication such that they were probably unable to detect even quite large reductions in prey populations (e.g. see analysis by Hall et al. 1990, Raffaelli \& Hall 1992). This problem seems to be a particular feature of experiments designed to assess the effects of larger vertebrate predators, such as shorebirds and fish, perhaps because of the use of fewer larger exclosures (e.g. 1 to $2 \mathrm{~m}^{2}$ ) in comparions to those for smaller predators like shrimps and crabs. Here we report a predator exclusion experiment which to our knowledge had a much higher level of replication than studies previously reported and also had good control of intra-replicate variability. Thus our experiment probably provides the most reasonable test to date of whether shorebirds and fish affect their prey densities. Specifically, we assessed the role of waders and eagle rays Myliobatis tenuicaudatus in influencing infaunal densities and macrobenthic community structure, within the context of seasonal density changes of both predators and prey, on an extensive sandflat in Manukau Harbour, New Zealand.

Shorebirds are often conspicuous predators on intertidal flats (e.g. Goss-Custard 1977, O'Connor \& Brown 1977, Schneider 1978, Evans et al. 1979, Schneider \& Harrington 1981, Quammen 1984). Potentially they can have important effects by focusing their feeding on high density patches of particular size classes of prey (O'Connor \& Brown 1977, Sutherland 1982), which in turn can influence prey population stability and interactions with other residents (Schneider 1992). The sandflats of Manukau Harbour are one of the richest shorebird habitats in New Zealand (Veitch 1978). Unlike many Northern Hemisphere situations, the total number of shorebirds does not undergo large seasonal changes associated with migration; shorebird densities range from about 30000 to 40000 over the harbour (340 $\mathrm{km}^{2}$ area) as a whole (Veitch pers. comm.). Common species include permanent residents (the variable oystercatcher Haematopus unicolour and the New Zealand dotterel Charadrius obscurus) which are joined in winter by other endemic waders (the South Island pied oystercatcher Haematopus ostralegus finschi, the banded dotterel Charadrius bicinctus, the wrybill Anarhynchus frontalis, and the pied stilt Himantopus himantopus), and in summer by wintering arctic breeding waders (mainly, the eastern bar-tailed godwit Limosa lapponica baueri and the knot Calidris canutus canutus) (Veitch 1977, 1978). Gulls (southern black-backed Larus dominicanus and red-billed Larus scopulinus) are also common in the harbour.

Over summer (November to March), eagle rays feed in and around the study area. In contrast to the focused feeding exhibited by shorebirds, where prey are individually extracted from the sediment, rays disturb the intertidal flats by jetting water into the sediment to create elliptical cone shaped pits (Gregory et al. 1979). The intensity of ray predation is indicated by their sediment disturbance rate of about $10 \mathrm{~m}^{2}$ of sandflat per day (Thrush et al. 1991) which is similar to disturbance rates observed for dasyatid rays in South Carolina (Grant 1983) and Florida (Reidenauer \& Thistle 1981, Sherman et al. 1983), USA.

Based on preliminary observations of bird feeding, the literature (e.g. Goss-Custard 1980, Evans et al. 1984, Baird et al. 1985, Wilson 1991, Zwarts \& Blomert 1992) and previous studies (Thrush et al. 1991) we expected infaunal bivalves to be an important component of the diet of shorebirds and eagle rays at this site. We assessed the role of the 2 different types of predator within the context of seasonal density changes of infauna (particularly common bivalves) and the seasonal absence of eagle rays. Information on changes in predator effects with time was obtained by sampling the experiment on 2 occasions; once when rays were absent and bivalve densities were high following recruitment, the other when both birds and rays were present and bivalve population structure was not dominated by new recruits.

\section{METHODS}

Study site. Manukau Harbour $\left(37^{\circ} 02^{\prime} \mathrm{S}, 174^{\circ} 41^{\prime} \mathrm{E}\right)$, is a large $\left(340 \mathrm{~km}^{2}\right)$ shallow inlet, adjacent to Auckland, on the west coast of the North Island of New Zealand. This study was conducted in the mid-tide zone of an extensive bivalve dominated sandflat adjacent to Wiroa Island. The sandflat was composed predominantly of well-compacted fine sand usually covered by ripples ( 0 to $2 \mathrm{~cm}$ in height), and homogeneous in visible physical characteristics. Sediments were unvegetated and not extensively modified by infaunal bioturbation; ray pits were the only large biogenic features on the sandflat. In this area the intertidal distance is about $1.8 \mathrm{~km}$, with a gradient across the flats of $0.097^{\circ}$ (T. Dolphin pers. comm.). Smaller predators which feed on the sandflats include juvenile fish, shore crabs, shrimps and a variety of infauna (nemerteans, amphipods and polychaetes), none of which were considered likely to be directly affected by our experimental exclusions. Further details of this sandflat are provided elsewhere [site AA in Pridmore et al. (1990) and site BD in Thrush et al. (1991)].

The temporal changes in macrofaunal densities were known from a $9000 \mathrm{~m}^{2}$ site adjacent to the area used for the experiment. Every $2 \mathrm{mo}$, since October 1987 , 12 core samples $(13 \mathrm{~cm}$ diam., $15 \mathrm{~cm}$ depth) have been collected from this site (authors' unpubl. data). Bivalve populations show interannual variability in the intensity of recruitment, although their recruitment times 
are consistent. The most common bivalves [Macomona (Tellina) liliana and Austrovenus (Chione) stutchburyi] recruit from February to April and exhibit stable basal populations. Typically, polychaetes and crustaceans attain their highest densities from April to October, with most populations fluctuating around consistent mean densities. At this adjacent site, the density of $M$. liliana was at basal levels when the experiment was initiated in January 1990 (mean 18.3 per core, $\mathrm{SD} \pm 6.2$ ), decreasing after recruitment on the first sampling occasion in July 1990 (mean 57.9 per core, $\mathrm{SD} \pm 11.8$ ) and again at basal densities when the experiment was finally sampled in March 1991 (mean 19.2 per core, $\mathrm{SD} \pm 5.5$ ). A. stutchburyi exhibited poor recruitment over the duration of the experiment, although densities were higher in July 1990 (mean 5.0 per core, $\mathrm{SD} \pm 2.4$ ) than in March 1991 (mean 2.8 per core, $\mathrm{SD} \pm 1.6$ )

Experimental design. In order to separate the effects of the 2 types of predator, 3 treatments were used: reference plots, where birds and fish could feed normally, plots which excluded birds, and plots which excluded both rays and birds (hereafter rays + birds). Fifteen replicates of each treatment were used, each replicate covering $2 \times 2 \mathrm{~m}$ and separated from adjacent replicates by $13 \mathrm{~m}$. The experimental design consisted of an $8 \times 6$ Latin Square with missing plots randomly allocated.

Reference plots were marked by corner stakes only. Birds were excluded by connecting corner stakes with string lines tied with white nylon tapes which flapped in the breeze. Similar bird exclusion techniques have been used successfully by Raffaelli \& Milne (1987) and Huxham (1993). Ray + bird exclusions consisted of $10 \mathrm{~cm}$ diam. mesh screens (made of fine wire) positioned $20 \mathrm{~cm}$ above the sediment surface to form sideless roof-only cages. Initial intensive observations of birds and sediment features (bird footprints, ray pits and ripples) demonstrated that predator exclusions were completely effective. Ray pits were observed inside bird exclusion plots, indicating these plots did not influence the feeding behaviour of the fish. Bird foot prints and ray pits were found around, but not in the ray + bird exclusion plots and birds were observed feeding around but not in the bird exclusion and the ray + bird exclusion plots. Exclusion structures used in this experiment were as open as possible to minimize any potential flow artifacts. Sediment ripples within plots were similar in size and orientation to those in surrounding sediments. On at least fortnightly intervals throughout the experiment observations were also made of birds and sediment features within the study site. Birds or their footprints were never seen in exclusion plots and birds were never seen standing on experimental structures. Ray pits were never observed in ray exclusions, although they were observed within reference and bird exclusion plots at a similar frequency. Also on these occasions exclusion structures were cleaned of any fouling material; this consisted of barnacles and small quantities of drifting weed. Experimental structures never became so fouled as to obviously modify flow, shade or enrich sediments.

Sampling. The experiment was set up in January 1990. Each plot was sampled on 2 separate occasions. The first occasion was in July 1990, 6 mo after the initiation of the experiment. At this time bivalve densities were expected to be high, and, although birds were present, rays had been absent from the sandflats for about 4 mo. The second sampling occasion, March 1991, was 14 mo after the initiation of the experiment, when rays had been feeding on the sandflat for about $4 \mathrm{mo}$.

On each sampling occasion the first $30 \mathrm{~cm}$ within the perimeter of each replicate was not sampled. On the first occasion, 3 core samples $(13 \mathrm{~cm}$ diam. and $15 \mathrm{~cm}$ depth) were taken from one half of each plot (total area sampled about $0.04 \mathrm{~m}^{2}$ per plot). For all analyses the 3 core samples from within each replicate were pooled. On the second sampling occasion the same protocol was used to sample the opposite half of each plot. On this occasion one of the ray + bird exclosures had become damaged; consequently only 14 replicates from each treatment were sampled. Cores ( 3 per replicate) were collected 30 to $50 \mathrm{~cm}$ from outside of each plot on the first sampling occasion in case large-scale spatial patterns of infauna confounded analysis (see Thrush 1991). As no such patterns were revealed this sampling was not repeated on the second occasion.

After collection samples were sieved (500 $\mu \mathrm{m}$ mesh) and the residue fixed in $5 \%$ formalin and $0.1 \%$ Rose Bengal in seawater. In the laboratory, macrofauna were sorted, identified to the lowest possible taxonomic level, counted and preserved in $70 \%$ isopropanol. Individuals of the common bivalves Macomona liliana and Austrovenus stutchburyi were measured (longest shell axis) to the nearest $0.1 \mathrm{~mm}$ using a dissecting microscope, camera lucida and digitizer for individuals smaller than $20 \mathrm{~mm}$ or vernier calipers for larger specimens.

To determine whether the exclosures had modified sediment topography or flow characteristics, the surficial sediment ( 0 to $2 \mathrm{~cm}$ ) grain size was analysed (after Folk 1968). Samples from replicates of a particular treatment, collected at the end of the experiment, were pooled to assess any major differences in grain size between treatments. Surficial sediment chlorophyll a concentrations were also measured on each sampling occasion, as microphytobenthos were expected to respond rapidly to changes in sediment characteristics. 
Chlorophyll a was extracted from the sediment by boiling in $90 \%$ ethanol for 10 min within a few hours of collection. The extract was filtered (Whatman GF/F filters) and its absorbance read at 750 and $665 \mathrm{~nm}$ using a Shimadzu UV/120/02 spectrophotometer. Corrections for phaeophytin were made following acidification of the sample to $7.5 \mathrm{mM} \mathrm{HCl}$ (see HowardWilliams et al. 1989 for further details).

Statistical analysis. As both predator and macrofaunal densities were expected to undergo large seasonal changes between the 2 sampling occasions, statistical analyses did not include time as a variable. Rather, data from the 2 sampling occasions were treated separately. Tests for significant differences between treatments were conducted on common taxa, i.e. those represented by an average of more than 1 individual per core. Generally, this equated to populations that were 1 of the 10 most abundant taxa found in at least 1 treatment on either sampling occasion. As spatial autocorrelation may influence statistical tests by effectively modifying the number of independent samples (Legendre 1993), individual taxa were analysed for spatial autocorrelation on the experimentwide scale using correlograms of Moran's spatial autocorrelation coefficient, $I$ (Wartenberg 1989). No significant spatial autocorrelation was demonstrated for any of the common taxa on the first sampling occasion. On the second sampling occasion only the cumacean Colurostylis lemurum was spatially autocorrelated (Moran's $I=0.45, \mathrm{p}=0.035$, distance class 1 to $15 \mathrm{~m}$ ), indicating that density estimates from adjacent plots were not truly independent.

Prior to tests for the significance of treatment effects, preliminary tests for normality (Shipiro-Wilk) and homogeneity of variance (Bartlett's) were conducted. When data did not conform to parametric assumptions, Kruskal-Wallis tests followed by multiple comparison tests described by Conover (1980) were used. Otherwise ANOVA followed by Scheffé multiple comparison tests were performed. The significance of statistical tests was assigned at the $5 \%$ level, except for Macomona liliana and Austrovenus stutchburyi where, due to tests on both overall densities and individual size classes, the significance level was modified by the Bonferroni procedure (Zar 1984). Tests on common taxa which did not demonstrate significant treatment effects were subjected to power analysis (Cohen 1988). Finally, differences between the overall assemblages in the 3 treatments were assessed using ANOSIM (Clarke \& Green 1988, Clarke 1993). This randomization/permutation procedure tests for differences in terms of both location and variability in the ranked similarity matrix generated using the Bray-Curtis similarity index (Bray \& Curtis 1957)
Table 1. Grain size characteristics from the 3 treatments, based on pooled samples collected at the end of the experiment

\begin{tabular}{lccc|}
\hline & Reference & $\begin{array}{c}\text { Bird } \\
\text { exclusion }\end{array}$ & $\begin{array}{c}\text { Ray + bird } \\
\text { exclusion }\end{array}$ \\
\hline $\begin{array}{l}\text { Graphic mean ( } \phi) \\
\begin{array}{l}\text { Inclusive graphic } \\
\text { standard deviation }\end{array}\end{array}$ & 2.88 & 2.74 & 2.93 \\
$\begin{array}{l}\text { Inclusive graphic } \\
\text { skewness }\end{array}$ & 0.30 & 0.35 & 0.33 \\
$\begin{array}{l}\text { Inclusive graphic } \\
\text { kurtosis }\end{array}$ & 1.24 & 1.94 & 1.17 \\
$\%$ Gravel (shell) (>1 mm) & 0.7 & 1.1 & 0.4 \\
\% Sand (0.0625-1 mm) & 98.9 & 98.1 & 98.7 \\
$\%$ Mud (<0.0625 mm) & 0.4 & 0.8 & 0.9 \\
\hline
\end{tabular}

\section{RESULTS}

\section{Sediment characteristics}

Sediments from the 3 treatments were all well-sorted fine sands with near symmetrical and very leptokurtic distributions (Table 1). Analysis of surficial sediment chlorophyll a concentrations (Table 2) demonstrated no significant difference between treatments on the first sampling occasion. There was an overall significant difference between treatments on the second sampling occasion, but multiple comparisons test failed to consistently identify differences between treatments. The uniformity of visible sediment characteristics (sediment height, size and orientation of ripples) suggested the experimental structures did not modify sediment or flow patterns. The small amount of fouling which built up between cleaning intervals and the turbulent conditions in this habitat make it unlikely that sediment shading or nutrient additions would have resulted from experimental structures.

Table 2. Surficial sediment chlorophyll a concentrations $\left(\mu \mathrm{g} \mathrm{cm}^{-2}\right)$ and results of ANOVA

\begin{tabular}{|c|c|c|c|c|}
\hline \multirow[t]{2}{*}{ Treatment } & \multicolumn{2}{|c|}{$6 \mathrm{mo}$} & \multicolumn{2}{|c|}{$14 \mathrm{mo}$} \\
\hline & Mean & SE & Mean & $S E$ \\
\hline Reference & 3.9 & 0.3 & 7.4 & 0.3 \\
\hline Bird exclusion & 4.0 & 0.2 & 8.1 & 0.4 \\
\hline Ray + bird exclusion & 3.8 & 0.3 & 9.2 & 0.4 \\
\hline ANOVA & \multicolumn{2}{|c|}{$\mathrm{p}=0.8924$} & \multicolumn{2}{|c|}{$\mathrm{p}=0.0037$} \\
\hline \multicolumn{3}{|c|}{ Multiple comparison test ${ }^{\star}$} & \multicolumn{2}{|c|}{ S B R } \\
\hline \multicolumn{5}{|c|}{$\begin{array}{l}{ }^{\circ} \mathrm{R} \text { : reference; B: bird exclusion; S: ray + bird exclusion } \\
\text { Letters connected by underlining are not significantly } \\
\text { different from each other }\end{array}$} \\
\hline
\end{tabular}




\section{Infaunal characteristics at 6 mo}

The macrobenthic assemblages in each of the 3 treatments were dominated by the bivalves Macomona liliana and Austrovenus stutchburyi and the spionid polychaete Scolelepis sp. No major difference in the dominance structure of the 3 treatments was observed. $M$. liliana populations in each treatment were dominated by small $(<4 \mathrm{~mm})$ individuals (Fig. 1). Abundances of medium to large sized $M$. liliana (>8 mm) were significantly different between treatments with the highest numbers being found in the bird exclusion and the lowest in the reference plots. Small $M$. liliana were significantly less abundant in the bird exclusion treatment (Table 3). The population structure of A. stutchburyi was also dominated by small $(<4 \mathrm{~mm})$ individuals. Small $A$. stutchburyi were significantly more abundant in the reference plots than in the 2 predator exclusion treatments (Table 3). Densities of large $(>8 \mathrm{~mm})$ A. stutchburyi were not significantly different between treatments.

Nine common taxa, including the 3 most abundant, showed significant treatment effects (Fig. 2). The density of Macomona liliana, influenced by the large proportion of small individuals, exhibited significantly lower densities in the bird exclusion treatment. Similar patterns were apparent for the bivalve Nucula hartvigiana, the polychaetes Scolelepis sp. and Heteromastus filiformis, and nemerteans. Only the amphipod Methalimedon sp. exhibited significantly higher densities in the bird exclusion treatment. $A$. stutchburyi exhibited significantly lower densities in the ray + bird exclusion. Densities of the bivalve Zenatia acinaces and the amphipod Paracalliope novizealandiae were significantly lower in both exclusion treatments.

The percentage changes in density achieved between the reference and the treatment from which it was significantly different ranged from $16 \%$ for Macomona liliana to $61 \%$ for Zenatia acinaces. In absolute terms, the statistically significant density changes ranged from an average of 1.1 ind. per 3 cores for Nucula hartvigiana to 35.4 ind. per 3 cores for M. liliana. Seven common taxa did not demonstrate significant treatment effects. Data for 2 of these, the cumacean Colurostylis lemurum and the polychaete Orbinia papillosa, violated normality and heterogeneity of variance assumptions, which precluded

Table 3. Results of tests for treatment effects on small and large size classes of Macomona liliana and Austrovenus stutchburyi sampled 6 mo after initiation of the experiment. ns: not significant

\begin{tabular}{|c|c|c|}
\hline Taxon and size class & p level & Resulta \\
\hline \multicolumn{3}{|l|}{ M. liliana } \\
\hline$<4 \mathrm{~mm}$ & 0.0077 & $S R>B$ \\
\hline$>8 \mathrm{~mm}$ & 0.0004 & B S R \\
\hline \multicolumn{3}{|l|}{ A. stutchburyi } \\
\hline$<4 \mathrm{~mm}$ & 0.0024 & $\mathrm{R}>\mathrm{B} \mathrm{S}$ \\
\hline$>8 \mathrm{~mm}$ & ns & \\
\hline \multicolumn{3}{|c|}{$\begin{array}{l}{ }^{\mathrm{d}} \mathrm{R} \text { : reference; } \mathrm{B} \text { : bird exclusion; } \mathrm{S} \text { : ray }+ \text { bird exclusion. } \\
\text { Letters connected by underlining are not significantly } \\
\text { different from each other }\end{array}$} \\
\hline
\end{tabular}

\section{Macomona liliana}

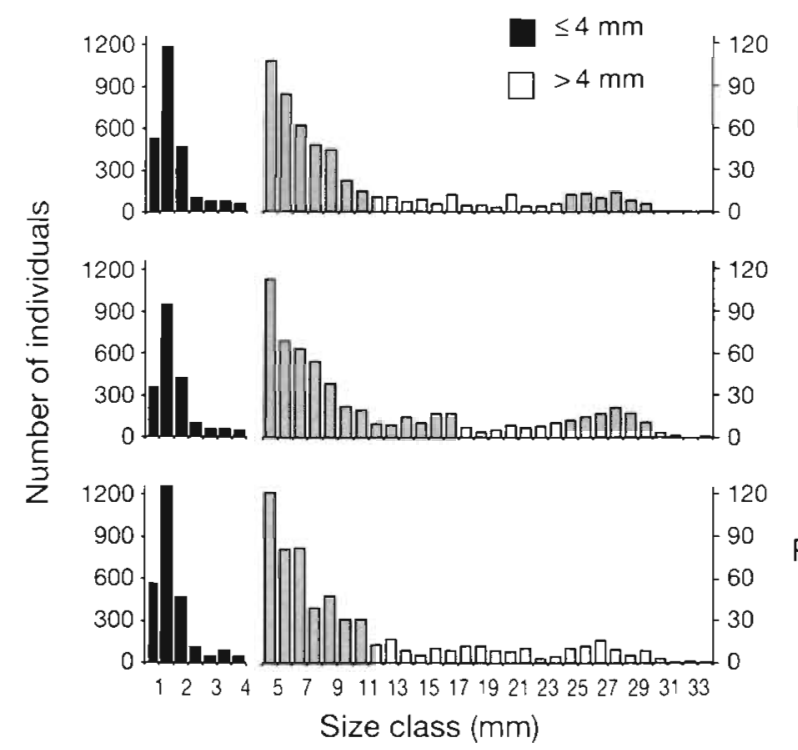

\section{Austrovenus stutchburyi}
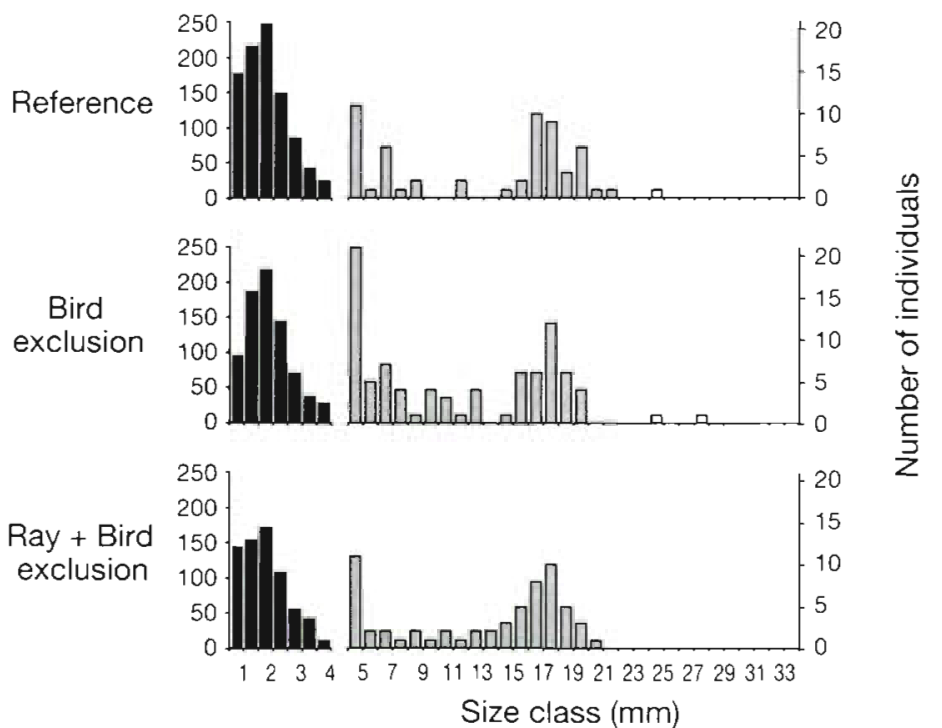

Fig. 1. Macomona liliana and Austrovenus stutchburyi. Size frequency distributions in the 3 treatments after 6 mo. Note the scale change after $4 \mathrm{~mm}$ 

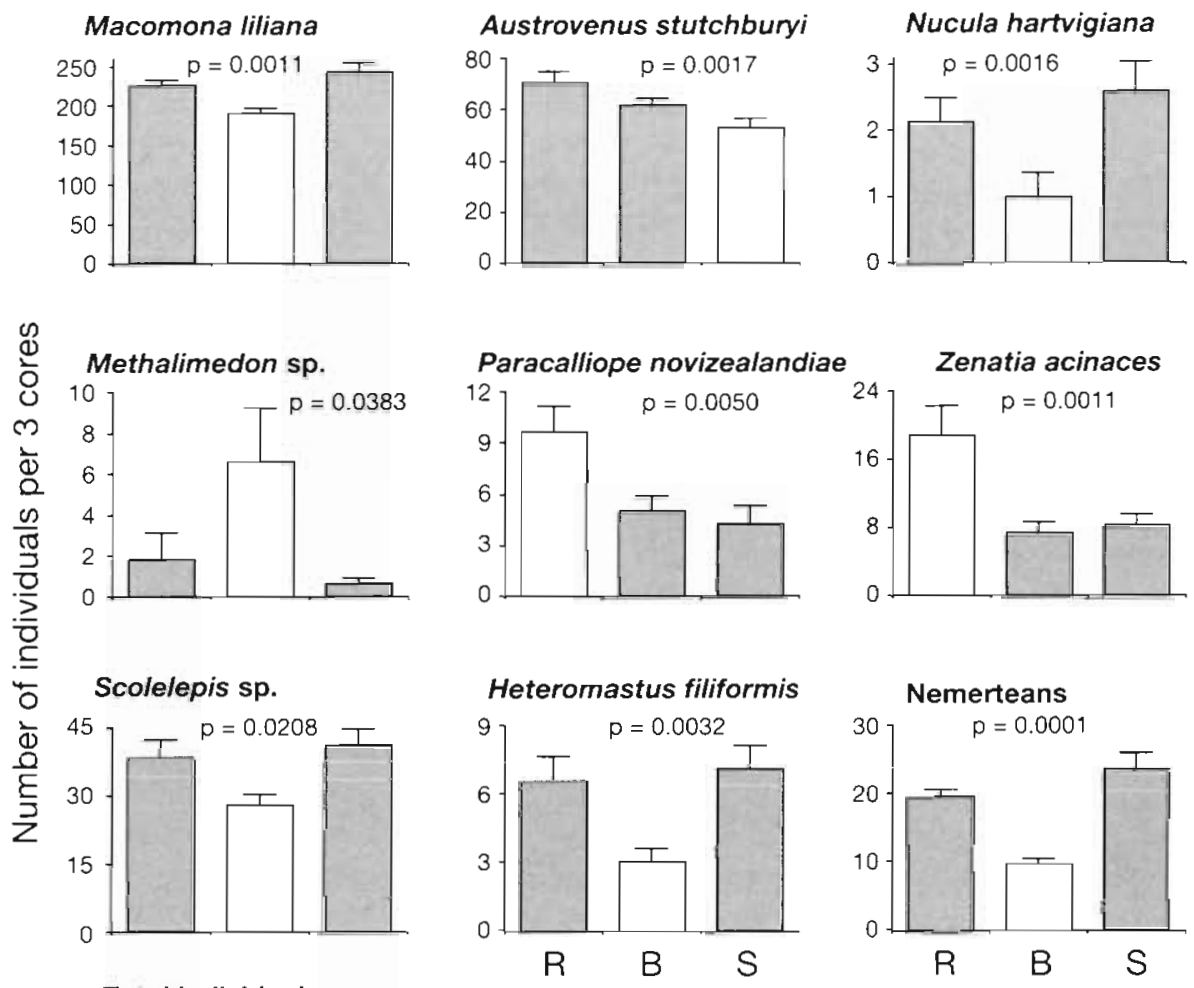

Total individuals

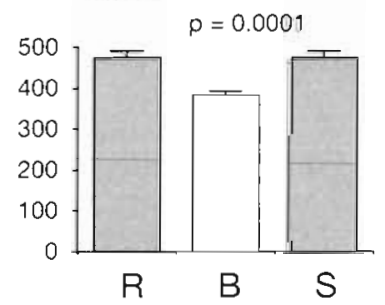

Fig. 2. Plots of mean abundance and standard error for taxa which recorded significant treatment effects after 6 mo. Unshaded bars represent significantly different treatments in multiple comparison tests. $R$ : reference plots; B: bird exclusion plots; S: ray + bird exclusion plots

assessing power. For the other 5 taxa the power to reject the null hypothesis with the effect size apparent from the experiment was low (Table 4). It is therefore possible that, even with the large number of replicates used, the non-significant results did not reflect a lack of treatment effects. However, both the proportional and the actual differences between treatments were generally smaller for these taxa than for those exhibiting significant treatment effects. Calculations of the number of treatment replicates needed to achieve $80 \%$ power for the effect size apparent in the experiment revealed logistically unfeasible numbers.

As expected, considering the numerical domination of the community by small Macomona liliana, the total number of individuals in the bird exclusion treatment was significantly lower than in the 2 other treatments (Fig. 2). No significant effects were found on the number of taxa (Table 4). Examination of the taxa lists from each treatment did not show any distinct patterns in the occurrence of rare taxa. ANOSIM assessment of differences in the ranked similarity matrix produced from individual treatment replicates demonstrated an overall significant difference between treatments $(\mathrm{p}=0.002)$ with a significant difference between each pairwise combination $(p<0.01)$.

Although rays had been absent from the sandflats for several months prior to this sampling occasion, bird exclusion and the ray + bird exclusion treatments did not produce similar patterns. Comparison of data from samples collected outside and inside of replicates revealed that the 5 taxa which exhibited significantly lower densities in the bird exclusion treatment all showed edge effects around the bird exclusion plots. This is illustrated for the bivalve Macomona liliana and the polychaete Heteromastus filiformis (Fig. 3) where mean and standard error values from outside the bird exclusion treatment are more similar to those from within this treatment than to those outside the other 2 treatments. This edge effect probably resulted from the inhibition of birds feeding right up to the exclosure 
Table 4. Power analysis conducted after non-significant test results from the first sampling occasion (6 mo)

\begin{tabular}{|c|c|c|c|c|c|c|}
\hline & $\begin{array}{c}\text { Aonides } \\
\text { oxycephala }\end{array}$ & $\begin{array}{c}\text { Magelona } \\
\text { ?dakina }\end{array}$ & $\begin{array}{c}\text { Mactra } \\
\text { ovata }\end{array}$ & $\begin{array}{l}\text { Hiatula } \\
\text { siliqua }\end{array}$ & $\begin{array}{l}\text { Waitangi } \\
\text { brevirostris }\end{array}$ & $\begin{array}{l}\text { Total no. } \\
\text { of taxa }\end{array}$ \\
\hline Power $(\%)$ & 44 & 14 & 38 & 55 & 35 & 18 \\
\hline Effect size & 0.32 & 0.16 & 0.29 & 0.37 & 0.27 & 0.16 \\
\hline Difference $^{a}$ & 6.9 & 2.0 & 1.3 & 2.9 & 3.4 & 0.7 \\
\hline $\begin{array}{l}\text { Proportional } \\
\text { difference }^{b}\end{array}$ & 0.33 & 0.17 & 0.28 & 0.29 & 0.26 & 0.03 \\
\hline $\begin{array}{l}\text { Replicates needed to } \\
\text { achieve } 80 \% \text { power }\end{array}$ & 80 & 80 & 80 & 52 & 80 & 140 \\
\hline \multicolumn{7}{|c|}{ a (Max. treatment mean) - (Min. treatment mean) } \\
\hline
\end{tabular}

edge because of the disturbance created by the flapping tapes. This effectively increased the area of bird exclusion plots, making them different from ray + bird exclusion plots, and may account for the different effects of the 2 exclusion treatments on this sampling occasion when rays were absent prior to sampling. The minimum distance of $13 \mathrm{~m}$ which separated replicate plots was sufficient to allow birds to move and feed and so these effects did not extend to produce a site-wide pattern of bird feeding behaviour.

\section{Infaunal characteristics after 14 mo}

Macomona liliana was still the most dominant species after $14 \mathrm{mo}$, although densities in all treatments had decreased by at least $50 \%$ from those observed on the first sampling occasion. Austrovenus stutchburyi had decreased in dominance in all treatments. Taxa classified as common in the 14 mo samples which were not common in the 6 mo samples were the holothurian Trochodota dendyi, the polychaete Travisia olens and the isopod Exosphaeroma spp. Taxa common on the first but not the second sampling occasion were the bivalve Nucula hartvigiana and the amphipods Methalimedon sp., Paracalliope novizealandiae and Waitangi brevirostris.
Densities of small $(<4 \mathrm{~mm})$ Macomona liliana and Austrovenus stutchburyi decreased markedly between the 6 and 14 mo sampling occasions (cf. Figs. 4 \& 1). On the 14 mo sampling occasion densities of large $M$. liliana (>8 mm) were significantly higher in the ray + bird exclusion treatment. No significant difference between treatments was apparent for small individuals of either species, or for large $(>8 \mathrm{~mm})$ individuals of A. stutchburyi (Table 5).

Six common taxa showed significant treatment effects (Fig. 5). Unlike the 6 mo results, more of the significant treatment effects were direct negative predator effects with the highest densities of Macomona liliana, Trochodota dendyi, Colurostylis lemurum and nemerteans occurring in the ray + bird exclusion. Scolelepis sp. was least abundant in the ray + bird exclusion, and Heteromastus filiformis was least abundant in the bird exclusion and most abundant in the reference. Although $C$. lemurum was spatially autocorrelated the degree of autocorrelation was unlikely to influence the observed significance of the test for treatment effects (Bartlett 1978). In fact, the difference observed between treatments was sufficiently large that even when the number of independent samples was reduced to remove spatial autocorrelation, significant treatment effects were still apparent. Density increases in the predator ex-
Fig. 3. Plots of mean abundance and standard error inside and outside (shaded blocks) treatment replicates, for 2 species, illustrating the edge effect around the bird exclosure replicates after 6 mo
Macomona liliana

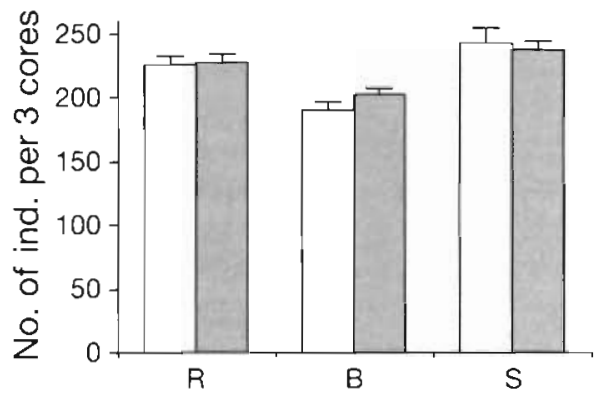

Heteromastus filiformis

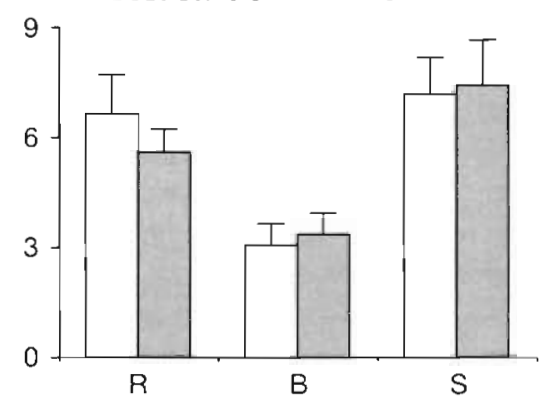



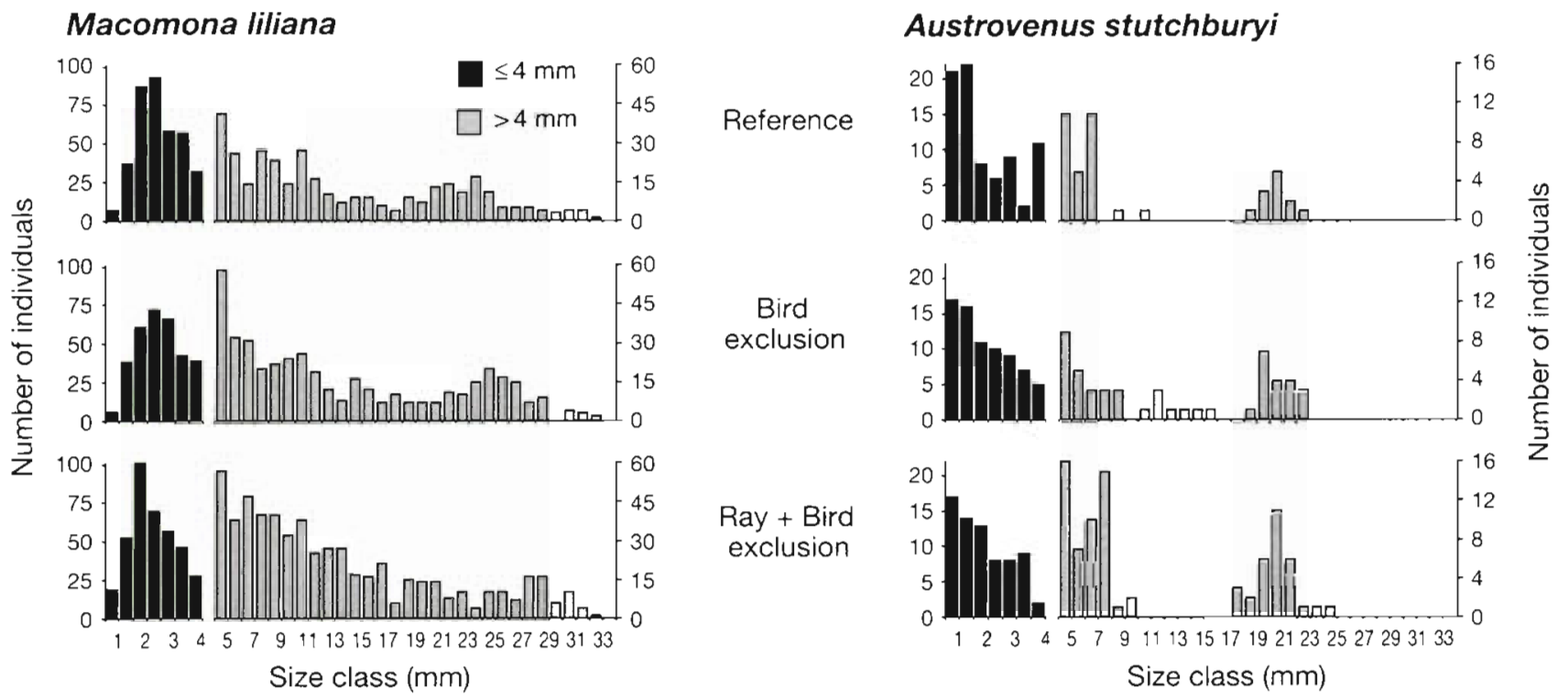

Fig. 4. Macomona liliana and Austrovenus stutchburyi. Size frequency distributions in the 3 treatments after 14 mo. Note the scale change after $4 \mathrm{~mm}$

clusion treatments produced percentage increases between the reference and the significantly different treatment ranging from $23 \%$ for C. lemurum to $54 \%$ for nemerteans. Scolelepis sp. and $H$. filiformis showed significant decreases in density relative to the reference of 58 and $71 \%$ respectively. The smallest statistically significant density change, in absolute terms, was achieved by $H$. filiformis which decreased in density by an average of 1.1 ind. per 3 cores. Of the 8 common taxa which did not show significant treatment effects Exosphaeroma spp. and Travisia olens violated the assumptions necessary for assessing power. For the others treatment differences were generally even smaller and the power to reject the null hypothesis even lower than on the first occasion (Table 6). For this experiment to have achieved $80 \%$ power with the small treatment effects apparent on this occasion, the number of replicates would have needed be extremely high for several species (Table 6). However, even though the treatment effects apparent from the experiment are small we remain unable to conclude that non-significant results reflect no treatment effects.

The total number of individuals and number of taxa were not significantly different between treatments (Table 6). Examination of the taxa lists from each of the 3 treatments did not reveal any clear patterns in the distribution of rare taxa. ANOSIM demonstrated a significant overall difference between treatments $(p=0.01)$ which resulted from a difference between the ray + bird exclusion and the other 2 treatments $(p<0.01)$.

\section{DISCUSSION}

In this experiment, effects of predator exclusion at the community level were principally driven by changes in the densities of some common taxa. On both sampling occasions significant treatment effects were apparent for about $50 \%$ of the common taxa. Direct negative effects of predators were apparent on large Macomona liliana on both sampling occasions, with higher densities in the bird exclusion treatment at 6 mo and in the ray + bird exclusion treatment at 14 mo. Bird exclusion had the greatest effect on infaunal densities on the first sampling occasion when recently recruited bivalves were abundant. However, at this time the density of most common taxa did not respond positively to preda-

Table 5. Results of tests for treatment effects on small and large size classes of Macomona liliana and Austrovenus stutchburyi sampled 14 mo after initiation of the experiment. ns: not significant

\begin{tabular}{|c|c|c|}
\hline Taxon and size class & p level & Result: ${ }^{d}$ \\
\hline \multicolumn{3}{|l|}{ M. Liliana } \\
\hline$<4 \mathrm{~mm}$ & ns & \\
\hline$>8 \mathrm{~mm}$ & 0.0001 & $\mathrm{~S}>\mathrm{B}>\mathrm{R}$ \\
\hline \multicolumn{3}{|l|}{ A. stutchburyi } \\
\hline$<4 \mathrm{~mm}$ & ns & \\
\hline$>8 \mathrm{~mm}$ & ns & \\
\hline \multicolumn{3}{|c|}{$\begin{array}{l}{ }^{\mathrm{N}} \mathrm{R} \text { : reference; } \mathrm{B} \text { : bird exclusion, } \mathrm{S} \text { : ray + bird exclusion. } \\
\text { Letters not connected by underlining are significantly } \\
\text { different from each other }\end{array}$} \\
\hline
\end{tabular}


Fig. 5. Plots of mean abundance and standard error for taxa which recorded significant treatment effects after 14 mo. Unshaded bars represent significantly different treatments in multiple comparison tests, bars with lighter shading represent gradations in density. $\mathrm{R}$ : reference plots; B: bird exclusion plots; S: ray + bird exclusion plots

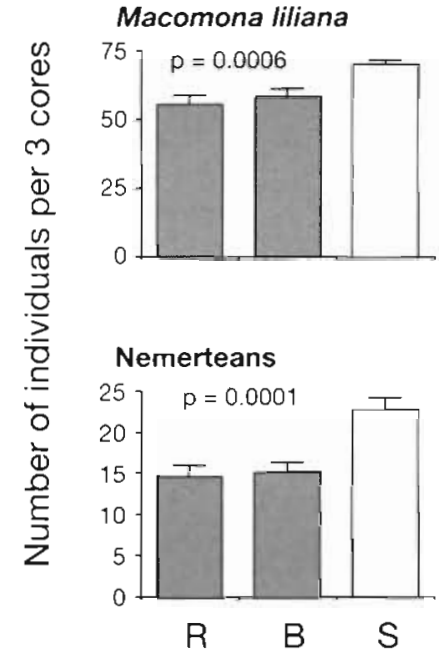

Colurostylis lemurum

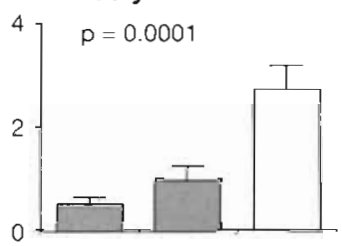

Scolelepis sp.

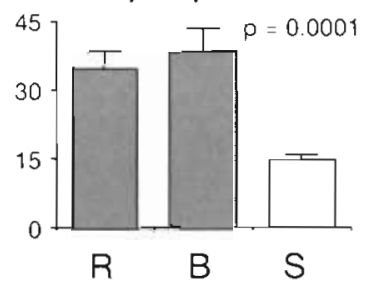

Heteromastus filiformis

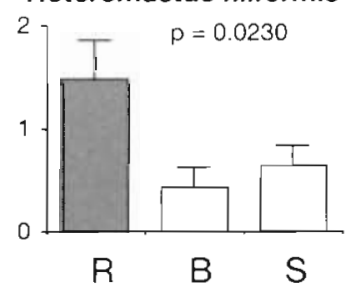

tor exclusion; instead, they decreased in abundance despite protection. The seasonality of effects in our experiment (i.e. the absence of rays during winter when bivalve populations were dominated by new recruits) precluded assessing the relative importance of the 2 types of predator at this time.

Shorebird predation over the period when bivalve recruitment was high demonstrated negative effects on large Macomona liliana and the amphipod Methalimedon sp. Most taxa which showed significant treatment effects on this occasion did not show an obvious direct response to predator exclusion. From our observations during the course of the experiment we are confident that both predator exclusion treatments excluded shorebirds, the experiment was not confounded by gross changes in sediment conditions, and rays had been absent from the sandflat prior to the first sampling occasion. To account therefore for the decreased density of small $M$. liliana in the bird exclusion treatment we postulate that the high density of large $M$. liliana had a negative effect on conspecific juveniles. In unvegetated soft-bottom habitats interactions between different size-classes of the dominant prey complicate the results of exclusion experiments. For example, as a result of excluding large predators Reise (1978) found increased densities of large shellfish and reduced densities of new recruits, whilst Kent \& Day (1983) demonstrated that adult nereid polychaetes suppressed the abundance of juvenile conspecifics, counterbalancing the effect of bird and fish exclusion. Also, Wilson (1989) found that the abundance of dominant prey species (amphipods) was low in predator exclusions although individual size and biomass were high. Our results for $M$. liliana are therefore consistent with an adult/juvenile interaction, although we have previously demonstrated a facilitative role for large $M$. liliana in the initial colonization of juvenile conspecifics (Thrush et al. 1992). However, density thresholds are often important in determining the outcome of species interactions (e.g. Strong 1986 , Weins 1986, Levin 1988, Dayton in press). The switch from the positive role previously demonstrated to the

Table 6. Power analysis conducted after non-significant test results from the second sampling occasion (14 mo)

\begin{tabular}{|c|c|c|c|c|c|c|c|c|}
\hline & $\begin{array}{c}\text { Aonides } \\
\text { oxycephala }\end{array}$ & $\begin{array}{l}\text { Austrovenus } \\
\text { stutchburyi }\end{array}$ & $\begin{array}{l}\text { Magelona } \\
\text { ?dakini }\end{array}$ & $\begin{array}{l}\text { Orbinia } \\
\text { papillosa }\end{array}$ & $\begin{array}{l}\text { Hiatula } \\
\text { siliqua }\end{array}$ & $\begin{array}{l}\text { Zenatia } \\
\text { acinaces }\end{array}$ & $\begin{array}{c}\text { Total } \\
\text { no. of ind. }\end{array}$ & $\begin{array}{c}\text { Total } \\
\text { no. of taxa }\end{array}$ \\
\hline Power $(\%)$ & $<5$ & 13 & 12 & 7 & 32 & 8 & 18 & 12 \\
\hline Effect size & 0.05 & 0.15 & 0.14 & 0.07 & 0.26 & 0.08 & 0.15 & 0.11 \\
\hline Difference ${ }^{a}$ & 1.5 & 1.7 & 1.4 & 0.6 & 1.5 & 0.8 & 10.1 & 0.5 \\
\hline $\begin{array}{l}\text { Proportional } \\
\text { difference }\end{array}$ & 0.08 & 0.13 & 0.15 & 0.10 & 0.30 & 0.24 & 0.05 & 0.03 \\
\hline $\begin{array}{l}\text { Replicates needed to } \\
\text { achieve } 80 \% \text { power } \\
{ }^{a} \text { (Max. treatment mea } \\
{ }^{b}[(\text { Max. treatment me } \\
{ }^{C} \text { Could not be calcula }\end{array}$ & $\begin{array}{l}\qquad 1000^{c} \\
\text { n) }-(\text { Min. tre } \\
\text { an) }-(\text { Min. tr } \\
\text { ted from Coh }\end{array}$ & $\begin{array}{l}\quad 300 \\
\text { tment mean) } \\
\text { atment mean)] } \\
\text { n }(1988)\end{array}$ & 80 & 140 & 100 & $>1000^{c}$ & 140 & 300 \\
\hline
\end{tabular}


negative interaction postulated here is likely at the higher $M$. liliana densities found in the bird exclosures (up to 5 times those recorded in our previous experiment), although specific experiments are required to determine whether this is indeed the case. Moreover, as a variety of other taxa (e.g. small Austrovenus stutchburyi and Nucula hartvigiana and Heteromastus filiformis) follow the same pattern as those exhibited by small $M$. Liliana, we suspect that $M$. Liliana could play a central role in influencing the density of other species, although the mechanism remains unknown at present. Indirect predator-mediated effects are common following predator density manipulations (Sih et al. 1985) and there is a general recognition that complex interactions are likely to be important in structuring soft-bottom communities (Kneib 1991). However, forecasting outcomes of indirect effects is difficult without a thorough (and usually unavailable) underslanding of how a given system functions. Indeed, one of the benefits of field experiments is that they can reveal such effects.

On our first sampling occasion, when rays had been absent from the sandflat for about 4 mo, we anticipated that the 2 predator exclusion treatments would have similar effects. This did not occur. However, an edge effect was noted around the bird exclusion replicates, suggesting that the actual area from which birds were excluded was larger than our plot area. This was probably the most important factor in accounting for why different effects were apparent. Even quite small changes in the area occupied by experimental replicates can have important effects on the observed processes (Smith \& Brumsickle 1989). Simple models of movement in or over sediments indicate cage experiments are likely to be highly susceptible to the size of the exclusion area (Frid 1989, Hall et al. 1990) because the movement of infauna can potentially swamp predator effects in experiments employing small caged areas. Movement over large distances by animals entering the water column (e.g. Dean 1978, Alldredge \& King 1980, Armonies 1992) or moving with sediment bedload (e.g. Emerson \& Grant 1992) further emphasises the importance of the area over which predators are excluded to the outcome of the experiment. With the increased area of the bird exclusion treatment relative to the ray + bird exclusion, infauna that are not highly mobile over large scales, such as medium to large sized $M$. liliana, became less likely to move out of the area from which predators were excluded. These higher densities of medium to large sized individuals may further influence smaller conspecifics and other taxa. Edge effects caused by predator behavioural responses to exclosures obviously have important implications in the design of predator exclusion experiments. If the inter-replicate distance is smaller than the size of the edge effect, replicates of one treatment may overshadow effects in other treatments. Potentially, experiments which exclude predators over small areas may not reveal prey responses because a sufficiently large area has not been considered to counter the effects of prey mobility.

Infaunal mobility and the scale of exclosures may also be the reasons why bird predation did not show as great an effect on the second sampling occasion as on the first. Rates of sediment turnover caused by eagle rays previously calculated for this sandflat (Thrush et al. 1991) indicate that sufficient time was available between sampling occasions for rays to turn over all the available area within the study site. Sediment disturbance by rays in both reference and bird exclosures would have enhanced the rates of infaunal movement and could have masked the effects of bird predation. While common sandflat species quickly recolonise infilling ray pits (Thrush et al. 1991), this exclusion experiment demonstrated that ray predation and the associated sediment disturbance have a negative effect on a number of common taxa.

Despite the high level of replication and the homogeneous habitat in which our experiment was conducted, the power of tests with non-significant results was too low to reject the null hypothesis (with the effect size apparent from the experiment). Essentially, power is dependent on the size of the difference in treatment means in relation to variation within treatments. For our experiment, a change in mean density of greater than $2 / 3$ of the median standard deviation is needed to give powerful tests. To increase our power to $80 \%$ (with the effect size observed) in most cases required vast increases in the number of replicates. The consequent increase in the area needed for the experiment would further increase the variance of density estimates, and the level of replication would probably have to be even higher than calculated. While proportional density differences which produced significant treatment effects were all greater than $15 \%$ in our experiment, actual density differences were in some cases very small. For example, we were able to detect differences in mean density of just over 1 ind. per 3 cores. Even the most ecologically trivial differences can be shown to be statistically significant with sufficient replication. But it is difficult to determine what size of absolute or proportional difference in density between treatments is meaningful. Hall et al. (1990) have suggested that changes in infaunal densities of $5 \%$ or less might be taken as indicative of a weak interaction between species. All of the statistically significant differences observed between treatments in our experiment resulted from much greater density differences. Given the results of the power analysis, it is unlikely that weak interactions could be 
identified without a very narrowly focused experiment and intensive sampling. In fact, Reise (1987) considers that assemblages organised by weak interactions are likely to be beyond the scale of resolution of field experiments.

Differences in the treatment effects recorded on the 2 sampling occasions emphasise the importance of not only both types of predator but also site history and the conditions prevalent during the experiment. The major impact of shorebird predation was evident when juvenile Macomona liliana were abundant and rays absent. At this time large $M$. liliana appeared to influence the density of small conspecifics and a variety of common infauna. If this is the case, higher densities of recruits could produce even more pronounced adult/juvenile interactions; in years of poor recruitment, juvenile densities may be too low to elicit such secondary responses amongst infauna. These factors illustrate the contingent nature of field experiments. While experiments could be designed that encompass variation up to geographic scale and assess the generality of the role of particular predators, such experiments are likely to be very expensive to implement if they are adequately replicated at all levels. Then, too, the time of initiation and the duration of the experiment could also influence the results (Brown et al. 1986, Carpenter 1988, this study) which would further expand and complicate the design of such all-encompassing experiments. Manipulative field experiments have proven invaluable in extending our understanding of the functioning of marine benthic systems, but it is important to design the experiment to fit within the dynamics of the system being studied. The scale over which processes are manipulated is also important in enhancing our ability to generalize from site-specific studies. This is illustrated in our experiment: spatially, through the interaction of edge effects and resident mobility on the effects of predator exclusion, and temporally, through adult/juvenile interactions associated with seasonal recruitment and predator exclusion.

Acknowledgements. Anne-Marie Swartz, Marty Fauval and Karl Mischewski helped with field work and preliminary sample sorting. We thank Paul Dayton, John Commito, Steve Hall and especially Dave Raffaelli for their comments on an early version of the manuscript.

\section{LITERATURE CITED}

Alldredge, A. L., King, J. M. (1980). Effects of moonlight on the vertical migration patterns of demersal zooplankton. J. exp. mar. Biol. Ecol. 44: 133-156

Armonies, W. (1992). Migratory rhythms of drifting juvenile molluscs in tidal waters of the Wadden Sea. Mar. Ecol. Prog. Ser. 83: 197-206
Baird, D., Evans, P. R., Milne, H., Pienkowski, M. W. (1985). Utilization by shorebirds of benthic invertebrate production in intertidal areas. Oceanogr. mar. Biol. A. Rev. 23: $573-597$

Bartlett, M. S. (1978). Nearest neighbour models in the analysis of field experiments. J. R. Stat. Soc. B 40: 147-174

Bell, S. S., Coull, B. C. (1978). Field evidence that shrimp predation regulates meiofauna. Oecologia 35: 141-148

Belsky, A. J. (1987). The effects of grazing: confounding of ecosystem, community and organism scales. Am. Nat. 129: $777-783$

Bray, J. R., Curtis, J. T (1957). An ordination of the upland forest communities of Southern Wisconsin. Ecol. Monogr 27: $325-349$

Brown, J. H., Davidson, D. W., Munger, J. C., Inovye, R. S (1986). Experimental community ecology, the desert granivore system. In: Diamond, J., Case, T. J. (eds.) Community ecology. Harper \& Row, New York, p. 41-62

Carpenter, S. R. (1988). Transmission of variance through lake food webs. In: Carpenter, S. R. (ed.) Complex interactions in lake communities. Springer-Verlag, New York, p. $119-135$

Clarke, K. R. (1993). Non-parametric multivariate analyses of changes in community structure. A.ust. J. Ecol. 18: 117-143

Clarke, K. R., Green, R. H. (1988). Statistical design and analysis for a 'biological effects' study. Mar. Ecol. Prog. Ser. 46: 213-226

Cohen, J. (1988). Statistical power analysis for the behavioural sciences. Hove and London, Hillsdale, NJ

Commito, J. A., Ambrose, W. G. Jr (1985). Multiple trophic levels in soft-bottom communities. Mar. Ecol. Prog. Ser 26: $289-293$

Conover, W. J. (1980). Practical nonparametric statistics, 2nd edn. J. Wiley \& Sons, New York

Dayton, P. K. (in press). Community landscape, scale and stability in hard bottom marine communities. In: Hildrew, A. G., Giller, P. S., Raffaelli, D. (eds.) Aquatic ecology, scale, pattern and processes. Blackwell Scientific, Oxford

Dean, D. (1978). Migration of the sand worm Nereis virens during winter nights. Mar. Biol. 45: 168-173

Emerson, C. W., Grant, J. (1992). The control of soft-shell clam (Mya arenaria) recruitment on intertidal sandflats by bedload sediment transport. Limnol. Oceanogr. 36: $1288-1300$

Evans, P. R., Goss-Custard, J. D., Hale, W. G. (1984). Coastal waders and wildlife in winter. Cambridge University Press, Cambridge

Evans, P. R., Herdson, D. M., Knights, P. J., Pienkowski, M. W. (1979). Short-term effects of reclamation of part of Seal Sands, Teesmouth, on wintering waders and Shelduck I. Shorebird diets, invertebrate densities, and the impact of predation on invertebrates. Oecologia 41: 183-206

Folk, R. L. (1968). Petrology of sedimentary rocks. Hemphilis, Austin, TX

Frid, C. L. J. (1989). The role of recolonization processes in benthic communities, with special reference to the interpretation of predator-induced effects. J. exp. mar Biol. Ecol. 126: 163-171

Goss-Custard, J. D. (1977). The ecology of the Wash. III. Density-related behaviour and the possible effects of a loss of feeding grounds on wading birds (Charadrii). J. appl. Ecol. 14: 721-739

Goss-Custard, J. D. (1980). Competition for food and interference among waders. Ardea 68: 31-52

Grant, J. (1983). The relative magnitude of biological and physical sediment reworking in an intertidal community. J. mar. Res. 41: 673-689 
Gregory, M. R., Ballance, P. F., Gibson, G. W., Ayling, A. M. (1979). On how some rays (elasmobranchia) excavate feeding depressions by jetting water. J. sedim. Petrol. 49 $1125-1130$

Hall, S. J., Raffaelli, D., Turrell, W. R. (1990). Predator-caging experiments in marine systems: a reexamination of their value. Am. Nat. 136: 657-672

Howard-Williams, C., Pridmore, R., Downes, M. T., Vincent, W. F. (1989). Microbial biomass, photosynthesis and chlorophyll a related pigments in the ponds of the McMurdo Ice Shelf, Antarctica. Antarct. Sci. 1: 125-131

Huxham, M. R. (1993). The role of parasites in food webs. Ph.D. thesis, University of Aberdeen

Kent, A. C., Day, R. W (1983). Population dynamics of an infaunal polychaete: the effect of predators on an adultrecruit interaction. J. exp. mar. Biol. Ecol. 73: 185-203

Kneib, R. T. (1991). Indirect effects in experimental studies of marine soft-sediment communities. Am. Zool. 31: 874-885

Legendre, P. (1993). Spatial autocorrelation: trouble or new paradigm? Ecology 74: 1659-1673

Levin, S. A. (1988). Pattern, scale, and variability: an ecological perspective. In: Hastings, A. (ed.) Community ecology. Lecture notcs in biomathematics. Springer-Verlag, Berlin, p. 1-12

O'Connor, R. J., Brown, R. A. (1977). Prey depletion and foraging strategy in the oystercatcher Haematopus ostralegus. Oecologia 27: 75-92

Peterson, C. H. (1979) Predation, competition, exclusion and diversity in the soft-sediment benthic communities of estuaries and lagoons. In: Livingston, R. J. (ed.) Ecological processes in coastal and marine systems. Plenum Press, New York, p. 233-264

Pimm, S. L. (1991). The balance of nature?: ecological issues in the conservation of species and communities. University of Chicago Press, Chicago

Pridmore, R. D., Thrush, S. F., Hewitt, J. E., Roper, D. S. (1990). Macrobenthic community composition of six intertidal sandflats in Manukau Harbour, New Zealand. N.Z. J. mar. Freshwat. Res. 24: 81-96

Quammen, M. (1984). Predation by shorebirds, fish and crabs on invertebrates in intertidal mudflats: an experimental test. Ecology 65: 529-537

Raffaelli, D., Hall, S. J. (1992). Compartments and predation in an estuarine food web. J. Anim. Ecol. 61: 551-560

Raffaelli, D., Milne, H. (1987). An experimental investigation of the effects of shorebird and flatfish predation on estuarine invertebrates. Estuar. coast. Shelf Sci. 24: 1-13

Reidenauer, J. A., Thistle, D. (1981). Response of soft-bottom harpacticoid copepod community to a stingray (Dasyatis sabina) disturbance. Mar. Biol. 6: 261-267

Reise, K. (1977). Predator exclusion experiments in an intertidal mud flat. Helgoländer wiss. Meeresunters. 30: $263-271$

Reise, K. (1978). Experiments on epibenthic predation in the Wadden Sea. Helgoländer wiss. Meeresunters. 31: 55-101

Reise, K. (1987). Experimental analysis of processes between species on marine tidal flats. In: Schultz, E. D., Zwolfer, H. (eds.) Potentials and limitations of ecosystems analysis. Ecological studies 61. Springer-Verlag, Berlin, p. 391-400

Schneider, D. (1978). Equalisation of prey numbers of migratory shorebirds. Nature 271:353-354

Schneider, D. C. (1992). Thinning and clearing of prey by predators. Am. Nat. 139: 148-160
Schneider, D. C., Harrington, B. A. (1981). Timing of shorebird migration in relation to prey depletion. Auk 98: $801-811$

Sherman, K. M., Reidenauer, J. A., Thistle, D., Meeter, D (1983). Role of a natural disturbance in an assemblage of free-living nematodes. Mar. Ecol. Prog. Ser. 11: 23-30

Sih, A., Crowley, P., McPeek, M., Petranka, J., Strohmeier, K. (1985). Predation, competition, and prey communities: a review of field experiments. A. Rev. Ecol. Syst. 16: 269-311

Smith, C. R., Brumsickle, S. J. (1989). The effect of patch size and substrate isolation on colonization modes and rate in an intertidal sediment. Limnol. Oceanogr. 34: 1263-1277

Strong, D. R. (1986). Density-vague population change. Trends Ecol. Evol. 1: 39-42

Sutherland, W. J. (1982). Spatial variation in the predation on cockles by oystercatchers at Traeth Malynog, Anglesey. II. The patterns of mortality. J. Anim. Ecol. 51: 491-500

Thrush, S. F. (1986). Community structure on the floor of a sea-lough: are large epibenthic predators important? J. exp. mar. Biol. Ecol. 104: 171-183

Thrush, S. F. (1991). Spatial patterns in soft-bottom communities. Trends Ecol. Evol. 6: 75-79

Thrush, S. F., Pridmore, R. D, Hewitt, J. E., Cummings, V. J (1991). Impact of ray feeding disturbances on sandflat macrobenthos: do communities dominated by polychaetes or shellfish respond differently? Mar. Ecol. Prog. Ser. 69: $245-252$

Thrush, S. F., Pridmore, R. D., Hewitt, J. E., Cummings, V. J. (1992). Adult infauna as facilitators of colonization on intertidal sandflats. J. exp. mar. Biol. Ecol.159: 253-265

Veitch, C. R. (1.977). Arctic waders wintering in New Zealand. Proc. N.Z. Ecol. Soc. 24: 110-112

Veitch, C. R. (1978). Waders of the Manukau Harbour and Firth of Thames. Notornis 25: 1-24

Virnstein, R. W. (1977). The importance of predation by crabs and fishes on benthic infauna in Chesapeake Bay. Ecology 58: $1199-1217$

Virnstein, R. W. (1979) Predation on estuarine infauna response patterns of component species. Estuaries 2 $69-86$

Wartenberg, D. (1989). SAAP - a spatial autocorrelation analysis programme, Version 4.3. Department of Environmental and Community Medicine, Robert Wood Johnson Medical School, University of Medicine and Dentistry of New Jersey, Piscataway

Weins, J. A. (1986). Spatial scale and temporal variation in studies of shrubsteppe birds. In: Diamond, J., Case, T J (eds.) Community ecology. Harper \& Row, New York p. $154-171$

Whitlatch, R. B. (1980). Patterns of resource utilization and coexistence in marine intertidal deposit-feeding communities. J. mar. Res. 38: 743-765

Wilson, W. H. Jr (1989). Predation and the mediation of intraspecific competition in an infaunal community in the Bay of Fundy. J. exp. mar. Biol. Ecol. 132: 221-245

Wilson, W. H. Jr (1991). Competition and predation in marine soft-sediment communities. A. Rev. Ecol. Syst. 21:221-241

Zar, J. H. (1984). Biostatistical analysis. Prentice-Hall, Englewood Cliffs, NJ

Zwarts, L., Blomert, A. M. (1992). Why knot Calidris canutus take medium-sized Macoma balthica when six prey species are available. Mar. Ecol. Prog. Ser. 83: 113-128

Manuscript first received: November 1, 1993

Revised version accepted: January 27, 1994 